\title{
Pemantauan Kedisiplinan Siswa Melalui Penetapan Indikator Perilaku Disiplin Siswa Kelas III
}

\author{
Sasi Mardikarini*1, Laila Candra Kartika Putri ${ }^{2}$ \\ ${ }^{1,2}$ Program Studi Pendidikan Guru Sekolah Dasar, Fakultas Keguruan dan Ilmu Pendidikan, Universitas \\ Doktor Nugroho Magetan, Indonesia \\ e-mail: ${ }^{* 1}$ sasimardikarini09@udn.ac.id, ${ }^{2}$ lailacandra@gmail.com
}

\begin{abstract}
ABSTRAK
Tujuan dari penelitian ini, yaitu 1) untuk mengetahui perkembangan sikap disiplin siswa melalui penetapan indikator perilaku disiplin siswa di sekolah, dan 3) untuk mengetahui berbagai faktor yang mempengaruhi perkembangan sikap disiplin siswa. Penelitian ini merupakan jenis penelitian kualitatif. Sumber data yaitu guru kelas, kepala sekolah dan siswa kelas III. Teknik pengumpulan data dilakukan melalui wawancara, observasi, dan dokumentasi. Teknik analisis data terdiri atas tahap pengumpulan data, reduksi data, sajian data dan penarikan simpulan atau verifikasi. Berdasarkan hasil penelitian dan pembahasan terlihat bahwa, 1). Perkembangan sikap disiplin siswa dilihat dari indikator disiplin siswa di kelas III SD Negeri 2 Sriti menunjukkan perkembangan yang cukup baik. Hasil kegiatan tersebut menunjukkan perubahan yang cukup signifikan dan terlihat perkembangan dalam kedisiplinan siswa. 2) Faktor-faktor yang mempengaruhi perkembangan disiplin siswa di Kelas III SD Negeri 2 Sriti terdiri dari yaitu faktor internal dan faktor eksternal. Faktor internal merupakan faktor yang berasal dari dalam diri siswa sendiri, sedangkan faktor eksternal merupakan faktor yang berasal dari luar diri siswa, seperti guru kelas mereka, pihak sekolah, orang tua siswa, maupun teman-teman sekelas dan lingkungan sekitar mereka.
\end{abstract}

Kata kunci: Kedisiplinan, Indikator, Perilaku

This study aims 1) to determine the development of student discipline attitudes through the determination of indicators of student disciplinary behavior in schools, and 3) to determine the factors that influence the development of student discipline attitudes. The research method used is qualitative research. Sources of data are classroom teachers, principals and students in class III. Techniques of collecting data are interviews, observation, and documentation. Data analysis techniques include the stages of data collection, data reduction, data presentation and drawing conclusions or verification. Based on the results of research and discussion it can be seen that, 1). The development of students' disciplinary attitude seen from the indicators of student discipline in class III SD Negeri 2 Sriti showed a fairly good development. The results of these activities showed significant changes and seen developments in student discipline. 2) Factors that influence the development of student discipline in Class III SD Negeri 2 Sriti consist of 2 factors, namely internal factors and external factors. Internal factors are factors that come from within the students themselves, while external factors are factors that come from outside the students themselves, such as their class teachers, the school, parents of students, as well as classmates and their surroundings.

Keywords: Discipline, indicator, Attitude

\section{PENDAHULUAN}

Pelaksanaan pendidikan karakter di sekolah mulai diperhatikan sekarang ini. Karakter menjadi sesuatu yang harus dibiasakan dan ditanamkan sejak kecil pada diri seseorang. Salah satu bentuk penanaman karakter adalah dengan melakukan penguatan pendidikan karakter. Penguatan Pendidikan Karakter (PPK) merupakan pendidikan yang dilakukan oleh satuan pendidikan yang bertujuan untuk memperkuat karakter siswa melalui harmonisasi olah hati, olah rasa, olah pikir, dan olah raga dengan pelibatan dan kerja sama antara satuan pendidikan, keluarga, dan masyarakat sebagai bagian dari Gerakan Nasional Revolusi Mental (GNRM) [1]. Kegiatan ini 
Jurnal Ilmiah KONTEKSTUAL, Volume.2, No.01, Agustus 2020, pp. 30-37

dapat tercapai jika ada kerjasama antara pihak keluarga, satuan pendidikan, dan lingkungan masyarakat sekitar. Ketiga faktor tersebut sangat mempengaruhi terbentuknya karakter seseorang. Hal ini karena bahwa karakter tidak akan muncul begitu saja karena bukan sesuatu yang dimiliki sejak lahir" [2]. Karakter akan tertanam dengan baik jika dilakukan terus menerus oleh seseorang dan didukung oleh lingkungan yang memadai. Lingkungan yang dapat mendukung penanaman atau pembentukan karakter disebut lingkungan pendidikan. Lingkungan pendidikan pendidikan terdiri dari 1) pendidikan di keluarga (pendidikan informal), 2) pendidikan di sekolah (pendidikan formal), dan 3) pendidikan di masyarakat [3]. Salah satu lingkungan luar yang cukup penting dalam mendukung penanaman karakter ini adalah pendidikan di sekolah (lingkungan formal).

Di sekolah siswa akan mendapatkan pendidikan nilai. Pendidikan nilai diperlukan untuk memberikan dasar bagi siswa sebagai proses pembudayaan manusia [4]. Pendidikan nilai yang dimaksud dalam pernyataan diatas sejalan dengan karakter yang harus dikembangkan dalam pendidikan. Karakter yang ditanamkan kepada diri siswa banyak sekali jenisnya, antara lain jujur, tanggung jawab, disiplin, sopan, santun, dll. Pengembangan nilai karakter pada siswa disesuaikan dengan rencana pembelajaran dan kurikulum sesuai dengan kelas atau perkembangan siswa. Hal ini bertujuan agar nilai-nilai karakter dapat berkembang dalam diri siswa dan dapat dijadikan sebagai bekal kepribadian di masa depan. Penanaman ini bertujuan untuk menanggulangi karakter-karakter buruk pada diri siswa. Sesuai dengan perkembangan jaman akhir-akhir ini banyak dijumpai orang dengan pengetahuan yang sangat baik namun memiliki sikap dan keterampilan yang kurang baik.

Pendidikan karakter di usia dini juga dapat menghambat nilai- nilai kurang baik yang sering terjadi dan berkembang di sekolah. Salah satu pendidikan karakter yang cukup penting untuk ditanamkan sejak kecil adalah karakter disiplin. Nilai karakter disiplin akan mendorong tumbuhnya nilai-nilai karakter baik lainnya. Oleh sebab itu, karakter disiplin juga dapat dikatan sebagai karakter yang menjadi dasar pembentukan watak sesesorang. Disiplin dapat dikatan sebagai tindakan yang menunjukkan perilaku tertib dan patuh pada peraturan. Disiplin akan mendukung ketaatan dalam diri seseorang, sehingga sikap konsisten akan melekat dalam dirinya [5]. Karakter disiplin mendukung kepribadian anak untuk konsisten dalam berperilaku. Hal ini sangat baik jika dimiliki oleh setiap manusia, karena akan mendukung anak dalam berbagai kegiatan belajar. Pengembangan disiplin dalalm diri siswa akan membantu siswa mengembangkan control diri dan membantu anak mengenali perilaku yang salah lalu mengoreksinya [6]. Macam-macam disiplin yaitu disiplin otoritarian, disiplin permisif, dan disiplin demokratis [7]. Disiplin otoritarian bersifat memaksa kehendak orang lain. Disiplin permisif bersifat membebaskan seseorang untuk mengambil keputusan. Sedangkan, disiplin demokratis berusaha mengembangkan disiplin yang muncul karena kesadaran diri sehingga siswa memiliki disiplin diri yang kuat dan mantap. Karakter disiplin dapat dilaksanakan di sekolah dalam bentuk peraturan-peraturan yang dibuat antara pihak sekolah, guru, dan juga siswa. Keteraturan di sekolah dan ketaatan pada aturan merupakan salah satu faktor pendukung keberhasilan seseorang.

Disiplin merupakan salah satu unsur yang sangat penting bagi keberhasilan prestasi akademik siswa. Disiplin sekolah berperan penting dalam pencapaian harapan dan tujuan pembelajaran [8]. Penanaman karakter disiplin di sekolah perlu kerjasama berbagai pihak, karena tanpa kerja sama yang baik perilaku disiplin tersebut mustahil akan berhasil. Disiplin perlu diajarkan dan perlu dipelajari serta dihayati oleh siswa. Hal ini sejalan dengan pendapat yang menegaskan bahwa keberhasilan dan kegagalan sekolah dalam melaksanakan karakter disiplin sangat tergantung dari tingkat ketercapaian dalam menerapkan disiplin yang sempurna melalui beberapa pihak [9]. Disiplin dapat menjelaskan juga sebagai tugas-tugas perkembangan yang merupakan harapan masyarakat mengenai bagaimana anak dalam menjalankan tugas-tugas perkembangan secara efektif. Tugas-tugas perkembangan itu hanya dapat dilaksanakan oleh anak yang disiplin. Anak yang dapat menjalankan tugasnya, maka masyarakat akan menerimanya dengan baik. Dengan demikian, anak merasa dirinya bagian yang dapat diandalkan.

Demi tercapainya penanaman karakter disiplin di sekolah dengan baik, banyak hal yang dilakukan oleh pihak sekolah dan juga guru. Hal ini sesuai dengan tujuan dibentuknya 
Jurnal Ilmiah KONTEKSTUAL, Volume.2, No.01, Agustus 2020, pp. 30-37

kedisiplinan yaitu untuk mendidik siswa agar sanggup memerintahkan diri sendiri [10]. Hal tersebut antara lain pembuatan peraturan sekolah seperti jam masuk sekolah, pemakaian seragam sekolah, buang sampah sembarangan, dll. Selain itu terdapat juga peraturan kelas yang dibuat oleh guru seperti disiplin dalam mengumpulkan tugas, disiplin dalam masuk kelas saat bel pelajaran dimulai, dll. Berbagai jenis penanaman karakter disiplin dapat tercapai dengan berbagai cara dan proses yang tepat yang dapat dilakukan oleh sekolah. Cara dan proses tersebut harus dilaksanakan dengan tepat dan dalam waktu yang terus menerus baik dalam proses pembelajaran maupun di luar pembelajaran. Bahkan, orang tua di rumah juga harus bekerja sama dengan guru/ peraturan sekolah agar karakter disiplin dapat tertanam dengan maksimal.

Dunia pendidikan menghadapi tantangan tersendiri dalam mendisiplinkan siswanya, yaitu berkaitan dengan pemilihan cara yang tepat untuk menanamkan karakter disiplin [11]. Proses penanaman di luar pembelajaran dapat dimulai dengan membuat peraturan sekolah yang dipajang di kelas serta dijalankan bersama- sama anggota sekolah. Setelah dibuat peraturan, anggota sekolah harus bekerja sama untuk melaksanakannya dan memantau anak- anak yang melanggar peraturan sekolah. Selain aturan sekolah, guru di kelas juga perlu membuat aturan tersendiri, khususnya untuk pelaksanaan proses pembelajaran agar dapat berjalan dengan baik. Peraturanperaturan di kelas dibuat oleh guru kelas dan juga siswa, dan dipantau juga oleh guru dan siswa. Peraturan tersebut antara lain harus mengumpulkan tugas tepat waktu, harus kooperatif dalam pembelajaran, dll.

Penanaman karakter di dalam pembelajaran ini disesuaikan dengan kegiatan pembelajaran dan materi yang relevan. Proses penanaman karakter ini harus sejalan dengan materi pembelajaran yang ada. Sejalan dengan perkembangan pembelajaran saat ini, penggunaan kurikulum 2013 sangat mendukung adanya pembelajaran sikap yang salah satunya menanamkan sikap disiplin. Kurikulum 2013 edisi revisi bertujuan untuk menciptakan manusia Indonesia yang mampu berpikir kreatif, produktif, inovatif, proaktif dan afektif melalui pengembangan, keterampilan, dan pengetahuan secara integratif [12]. Oleh sebab itu, mengembangkan sikap, keterampilan, dan pengetahuan perlu berbagai cara agar dapat terlaksana secara efektif. Salah satu aturan dalam kurikulum 2013 dijelaskan, bahwa pengembangan sikap, keterampilan dan pengetahuan dapat berhasil jika guru membuat indikator pembelajaran masing- masing. Bahkan untuk saat ini, terutama pada kurikulum 2013 guru perlu membuat instrumen khusus untuk memantau dan menanamkan nilai/ sikap tertentu.

Instrumen untuk menilai karakter disiplin ini dapat dibuat sendiri oleh guru sesuai dengan karakteristik siswa di kelasnya. Guru memerlukan instrumen yang bisa digunakan untuk mengetahui kemampuan siswa dalam memahami materi tertentu [13]. Guru dapat membua instrumen di awal semester, di awal tema, maupun sebelum pelaksanaan pembelajaran. Instrumen ini berisi indikator penilaian disiplin, format penilaian disiplin untuk masing- masing siswa, hingga akhirnya nanti diresume untuk menjadi penilaian kepada siswa dan diberikan kepada wali murid/ orang tua. Saah satu tempat yang sudah mengaplikasikan instrumen ini di dalam sekolah adalah SD Negeri 2 Sriti. Guru SD Negeri 2 Sriti membuat instrumen penilaian sikap pembelajaran setiap awal semester. Salah satu sikap yang menjadi perhatian utama guru pada siswa kelas III SD adalah sikap disiplin.

Hasil observasi menunjukkan bahwa sebagian siswa di SD Negeri 2 Sriti sudah dapat menjalankan peraturan yang dibuat oleh guru. Dari 30 siswa, baru 18 siswa saja yang menjalankan aturan sekolah/ kelas. Sisanya, siswa belum dapat menerapkan aturan/ beberapa karakter yang ditanamkan di sekolah dengan maksimal. Berdasarkan hasil observasi awal, menurut guru kelasnya aturan- aturan yang belum dipatuhi oleh siswa antara lain beberapa siswa masuk terlambat ke sekolah, kurang lengkap dalam memakai seragam, dan tidak mengerjakan pekerjaan rumah atau tugas kelas. Aturan- aturan lain sering ngobrol sendiri saat jam pembelajaran, tidak mematuhi aturan kelas, dan membuang sampah di dalam kelas/ tidak pada tempatnya. Selain itu, beberapa siswa juga tidak mau melaksanakan jadwal piket, dan siswa tidak disiplin dalam masuk kelas untuk memulai pembelajaran. Mereka lebih sering bermain- main dulu di luar kelas sebelum mereka masuk kelas untuk pembelajaran, walaupun di kelas sudah ada guru. 
Jurnal Ilmiah KONTEKSTUAL, Volume.2, No.01, Agustus 2020, pp. 30-37

Kurang disiplinya siswa dengan aturan-aturan yang ada terutama dirasakan oleh guru kelas III. Menurut guru kelas, guru sudah menjelaskan dan memberi contoh mengenai aturan- aturan tersebut namun belum dilaksanakan oleh siswa. Selain itu, guru juga sudah sering memberikan hukuman kepada siswa jika mereka melakukan kesalahan. Saat observasi di kelas III, saat jam pelajaran pertama ditemukan beberapa siswa yang tidak mematuhi perintah guru selama proses pembelajaran. Siswa tersebut sudah beberapa kali ditegur oleh guru namun dia kembali tidak mematuhi perintah guru. Selain itu, ada salah seorang siswa yang datang terlambat dan diantar oleh orang tuanya. Orang tuanya beralasan bahwa anak tersebut datang terlambat karena bangun kesiangan. Selain itu, terdapat beberapa siswa yang memakai atribut seragam dengan tidak lengkap. Beberapa siswa tidak memakai sabuk, dasi, dan logo sekolah. Setelah ditanya kepada siswanya, alasan mereka karena seragam mereka baru dan orang tua mereka tidak membelikan atribut secara lengkap. Sehingga mereka memakai seragam yang seadanya di rumah. Dengan adanya kejadian tersebut, guru menegur siswa dan menyampaikannya pada orang tua dirumah. Namun, orang tua tidak langsung membenarkannya karena berbagai alasan.

Berdasarkan berbagai alasan tersebut, guru kelas dan sekolah mencari beberapa cara untuk menyelesaikan masalah kedisiplinan tersebut. Hal ini juga didukung oleh kewajiban melaksanakan Kurikulum terbaru yaitu Kurikulum 2013, dimana didalamnnya mewajibkan guru untuk menanamkan, memberi contoh, hingga melakukan penilaian secara autentik. Berdasarkan latar belakang tersebut, perlu dilakukan penelitian mengenai "Pemantauan Kedisiplinan Siswa Melalui Penetapan Indikator Perilaku Disiplin Pada Siswa Kelas III SD Negeri 2 Sriti Tahun Pelajaran 2018/2019".

\section{METODOLOGI PENELITIAN}

Tempat penelitian ini yaitu SDN 2 Sriti Kecamatan Sawoo Kabupaten Ponorogo. Waktu penelitian ini yaitu pada tahun ajaran 2018/2019 di semester genap. Penelitian ini merupakan penelitian kualitatif dengan jenis penelitian menggunakan deskriptif kualitatif. Penelitian kualitatif deskriptif adalah penelitian untuk memberikan uraian mengenai gejala, fenomena, atau fakta yang diteliti dengan mendeskripsikan tentang nilai variabel mandiri, tanpa bermaksud menghubungkan atau membandingkan [14]. Sumber data terdiri dari sumber data primer dan sumber data sekunder. Sumber data primer berasal dari kepala sekolah SD Negeri 2 Sriti, guru yang mengajar di kelas III, dan siswa kelas III. Data diambil dari observasi terhadap siswa selama proses pembelajaran, serta wawancara guru kelas III, siswa kelas III dan kepala sekolah. Sumber data sekunder diambil dari data- data pendukung yang dapat digunakan untuk menguatkan hasil observasi dan hasil wawancara. Data- data sekunder berasal dari dokumentasi (foto) selama peneliti melakukan penelitian di kelas, dan dokumentasi pendukung lainnya.

Teknik pengumpulan data dalam penelitian ini dilakukan dengan observasi, dokumentasi dan wawancara. Prosedur penelitian ini dilakukan dengan membuat proposal penelitian/ kajian pustaka, membuat surat ijin penelitian, membuat instrumen penelitian, melaksanakan penelitian, dan membuat laporan penelitian. Teknik keabsahan data pada penelitian ini dilakukan dengan triangulasi sumber, meningkatkan ketekunan, dan diskusi dengan teman sejawat. Teknik analisis data menggunakan analisis data model Miles dan Huberman yaitu data collection, data reduction, data display, dan conclusion [15].

\section{Hasil Penelitian}

\section{HASIL DAN PEMBAHASAN}

\section{a. Proses Perkembangan Sikap Disiplin Siswa Dilihat dari Indikator Disiplin Siswa di Kelas III SD Negeri 2 Sriti}

Proses perkembangan disiplin siswa di kelas dimulai dengan membuat peraturan kedisiplinan serta sanksi yang akan ditanggung siswa jika melanggar. Selanjutnya guru 
Jurnal Ilmiah KONTEKSTUAL, Volume.2, No.01, Agustus 2020, pp. 30-37

melakukan sosialisasi peraturan tersebut dan menempel peraturan tersebut di salah satu dinding kelas. Hal ini dilakukan oleh guru agar siswa mudah mengingat peraturan yang dibuat oleh guru. Selain itu, untuk memantau perkembangan disiplin siswa, guru membuat indikator penilaian kedisiplinan. Indikator tersebut dapat melihat perkembangan tingkat kedisiplinan siswa dari waktu ke waktu selama proses observasi. Hasil observasi menunjukkan bahwa 23 siswa mengalami perkembangan tingkat kedisiplinan, sedangkan 5 siswa lainnya dirasa belum terlihat perkembangan kedisiplinannya. Jumlah siswa yang mengalami perkembangan dalam kedisiplinannya tersebut sejalan dengan penilaian kedisiplinan yang dilakukan oleh guru kelas.

Selain itu, selama proses observasi yang dilakukan ditemukan juga beberapa temuan dalam penanaman kedisiplinan siswa. salah satu yang sering terjadi adalah pemakaian seragam sekolah yang tidak lengkap. Sering ditemukan siswa berangkat sekolah tanpa membawa dan memakai dasi merah. Alasan mereka beragam dari diletakkan di dalam tas, ada di laci meja sekolah, sampai alasan hilang, dan lupa dalam meletakkan. Berbagai langkah sudah diberikan guru dari memberi teguran, memberikan sanksi mendidik, sampai beberapa siswa diminta untuk pulang mengambil/ mencari dasinya sebelum masuk kelas. Proses perkembangan kedisiplinan di kelas II SDN 2 Sriti berkembang cukup baik. Siswa yang sebelumnya suka terlambat datang ke sekolah, hari demi hari menunjukkan perubahan yang baik. Mereka mulai datang tepat waktu sebelum pukul 7 di sekolah. Siswa juga menunjukkan perubahan sikapnya selama proses pembelajaran. Selama proses pembelajaran, siswa sudah mulai duduk dengan posisi yang baik dan melakukan eye contact yang baik dengan guru. Kejadian ini terlihat sangat baik dibandingkan sebelumnya karena siswa sudah tidak mengobrol sendiri dengan teman sebangkunya selama proses pembelajaran. Hal lain juga terlihat pada saat proses pemberian tugas. Sebagian besar siswa di kelas dapat menyelesaikan tugasnya tepat waktu. Beberapa siswa juga sudah tidak mendapatkan sanksi seperti sebelumnya.

\section{b. Faktor-Faktor yang Mempengaruhi Perkembangan Disiplin Siswa di Kelas III SDN 2 Sriti}

Proses perkembangan kedisiplinan siswa dapat dipengaruhi oleh beberapa faktor. Faktorfaktor tersebut terdiri dari faktor internal dan juga faktor eksternal dari diri siswa. Faktor internal yang sangat terlihat mempengaruhi kedisiplinan siswa adalah kemauan dari siswa untuk berubah. Penjelasan dan pemantauan guru secara terus menerus mengenai perkembangan kedisiplinan membuat mereka sadar bahwa kedisiplinan merupakan sesuatu yang wajib dimiliki oleh setiap orang. Selain faktor internal, ternyata faktor eksternal juga sangat mempengaruhi proses perkembangan disiplin siswa di kelas. salah satu faktor ekternal terbesar adalah dari guru. Seorang guru kelas selalu memberikan penjelasan mengenai pentingnya sikap disiplin pada diri siswa. Saat siswa melakukan kesalahan, guru juga tidak langsung memarahi siswa melainkan memberikan penjelasan agar siswa memahami apa yang dilakukannya memang salah. Guru menjelaskan kesalahan dan kedisiplinan dengan cukup sabar dan baik.

Faktor internal lainnya adalah lingkungan yang sangat mendukung. Lingkungan yang dimaksud dalam hal ini adalah peraturan kelas, sekolah, dan juga teman- teman sekelas. Kelas sebagai lingkunan terkecil memiliki peranan yang sangat baik untuk perkembangan disiplin siswa. Kelas didesain dengan sangat baik dan guru memberikan peraturan yang sangat baik di kelas untuk mendukung proses kedisiplinan. Hal ini juga sejalan dengan peraturan sekolah seperti datang tepat waktu, dan menutup gerbang sekolah tepat pukul 7 (tujuh) pagi. Apabila terdapat siswa atau guru yang terlambat datang ke sekolah akan diberikan sanksi sesuai dengan peraturan yang dibuat. Faktor internal lainnya adalah siswa/ teman sekelas. Sebagai teman sekelas, mereka akan selalu mengingatkan temannya apabila ketahuan berbuat salah baik terlihat oleh guru atau tidak. Dengan adanya pantauan dari teman-teman, siswa lain akan selalu merasa diawasi oleh sekitar dan tidak berani melakukan kesalahan.

Sedangkan untuk beberapa siswa yang belum menunjukkan perkembangan dalam kedisiplinan terjadi karena beberapa faktor juga. Salah satu faktor utama adalah kurang pahamnya siswa dengan peraturan yang berlaku di sekolah. Mereka tidak memiliki kemauan keras untuk berubah menjadi disiplin. Faktor lainnya yang mendukung adalah kurangnya dukungan dari pihak keluarga. Siswa yang kurang mengalami perkembangan dalam kedisiplinan adalah siswa yang 
Jurnal Ilmiah KONTEKSTUAL, Volume.2, No.01, Agustus 2020, pp. 30-37

kurang mendapat perhatian dari pihak keluarga mereka. Orang tua membebaskan anak untuk melakukan apapun yang mereka suka tanpa menjelaskan apakah yang mereka lakukan tersebut benar/ salah. Hal itu terjadi karena mereka memiliki orang tua yang cukup sibuk dengan urusan pekerjaan pribadi mereka sehingga menomorduakan tahap perkembangan anak. Kedisiplinan dapat tertanam dengan baik apabila adanya kerjasama antar semua lingkungan siswa seperti guru, teman, sekolah dan orang tua.

\section{Pembahasan \\ Proses Perkembangan Sikap Disiplin Siswa Dilihat Dari Indikator Disiplin Siswa di Kelas III SD Negeri 2 Sriti}

Penanaman kedisiplinan yang diterapkan oleh guru kepada siswa harus sesuai dengan pembelajaran yang diberikan. Penanaman kedisiplinan pada diri siswa perlu ditanamkan, diberi contoh/ panutan, dan pemantauan secara berkala. Hal ini dilakukan karena sebuah karakter dapat tertanam pada diri siswa melalui sebuah pembiasaan. Proses penanaman kedisiplinan pada diri siswa dimulai dengan perencanaan yang matang dari pihak guru dan sekolah dan lingkungan yang menyertainya. Guru dan instansi sekolah mencari berbagai cara agar proses penanaman kedisiplinan ini dapat berjalan maksimal. Hal ini dimulai dari membuat peraturan, memberikan contoh, memberi sanksi, mencatat perkembangan kedisiplinan pada buku penilaian sikap harian, hingga bekerja sama dengan orang tua siswa. Selanjutnya, guru memajang peraturan dan sanksi di papan kelas agar siswa tahu kesalahan-kesalahan mereka lalu guru menjelaskan kapan dimulai peraturan tersebut. Selama proses pelaksanaan kedisiplinan diterapkan, guru harus selalu memantau kegiatan siswa apabila terdapat siswa yang melakukan kesalahan. Apabila terdapat siswa yang melakukan kesalahan, guru segera melakukan tindakan dengan memberinya sanksi mendidik dan menasehatinya agar tidak mengulanginya kembali.

Guru juga memantau dan mencatat setiap kesalahan atau perubahan baik yang dilakukan oleh siswa sesuai indikator yang telah dibuatnya. Hal ini sejalan dengan yang dilakukan oleh peneliti selama melakukan pengamatan di kelas III. Peneliti mengamati siswa selama di sekolah dan mencatat perkembangan kedisiplinan siswa sesuai dengan indikator yang telah dibuat. Hasil pengamatan menunjukkan selama tiga minggu ini siswa banyak yang mengalami kemajuan dalam perkembangan kedisiplinan. Beberapa siswa terlihat sudah mengikuti aturan yang dibuat oleh guru, jarang ada siswa yang terlambat datang ke sekolah dan siswa mulai memakai seragam sekolah sesuai aturan yang ada. Berdasarkan hasil pengamatan, dari 28 siswa kelas III, terlihat 23 siswa mengalami perkembangan yang cukup signifikan. Selama proses pengamatan ditemukan bukti bahwa siswa yang awalnya bandel dan tidak mematuhi aturan sekolah, mereka mulai mengikuti aturan yang dibuat oleh sekolah dan aturan kelas.

\section{Faktor-Faktor yang Mempengaruhi Perkembangan Disiplin Siswa di Kelas III SDN 2 Sriti}

Proses pelaksanaan pemantauan kedisiplinan siswa dipengaruhi oleh banyak faktor, baik faktor intern maupun faktor ekstern dari siswa. Sebagian siswa mengalami perkembangan dalam proses kedisiplinan berawal dari paksaan peraturan sekolah/ kelas dan juga lingkungan. Hal ini terlihat dari kondisi awal yaitu siswa banyak yang tidak sesuai dengan aturan dan tidak mau mematuhi aturan yang berlaku. Setelah itu, guru menjelaskan tentang kedisiplinan dan membuat peraturan beserta sanksi yang diberikan. Hal ini menunjukkan bahwa siswa sudah mengikuti peraturan ini walaupun dengan terpaksa. Namun, karena sikap terpaksa tersebut lama- lama berubah menjadi kebahagiaan disaat siswa diberikan reward oleh guru saat dia melaksanakan kedisiplinan di kelas. Hal ini sejalan dengan pendapat yang menggolongkan unsur- unsur disiplin yaitu 1) Peraturan dapat berfungsi sebagai pedoman penilaian yang cukup baik, 2) hukuman yang diberikan berupa hukuman mendidik dan bertujuan agar siswa sadar dan tidak akan mengulanginya lagi, serta 3) pemberian hadiah untuk siswa yang mengalami perkembangan nilai yang baik sebagai acuan agar siswa lain termotivasi. [16]

Pendapat tersebut menunjukkan bahwa proses disiplin bisa terjadi karena berbagai faktor dan unsur-unsur yang mendukungnya. Unsur-unsur pendukung seperti peraturan, hukuman dan hadiah tersebut dipengaruhi juga oleh faktor eksternal siswa. Dalam artian, proses kedisiplinan 
Jurnal Ilmiah KONTEKSTUAL, Volume.2, No.01, Agustus 2020, pp. 30-37

seseorang dipengaruhi juga oleh orang sekitarnya seperti guru, orang tua, pihak sekolah, dan orang tuanya. Guru merupakan faktor eksternal utama yang mendukung proses kedisiplinan berkembang dengan baik di dalam pembelajaran maupun di sekolah. Hal ini karena guru merupakan penentu utama dalam proses pembelajaran. Apabila guru tegas dalam pengkondisian siswa, maka siswa juga akan menghargai dan mengikuti peraturan guru. Namun, apabila guru tidak aktif dalam pemantauan kedisiplinan, maka siswapun akan semakin tidak mengikuti peraturan. Hal ini juga berlaku pada kedisiplinan di dalam proses pembelajaran.

Selain guru, pihak sekolah juga menjadi salah satu penentu terlaksananya kedisiplinan siswa di sekolah. Dengan kerjasama yang baik dari pihak sekolah, maka siswa juga akan terbiasa dengan peraturan sekolah. Membangun karakter siswa sekolah perlu menerapkan tiga program, yaitu: 1) kultur sekolah bermutu yang mencakup mutu input, mutu akademik, dan mutu nonakademik; 2) kultur sekolah Islam dengan fokus penanaman karakter religius, keterbukaan, kepedulian, kebersamaan, dan kerja sama; 3) kultur disiplin dengan fokus penanaman karakter antara lain religius [17].

Kedisiplinan siswa di sekolah juga dipengaruhi oleh kedisiplinan orang tua dan lingkungan siswa di dalam kelas. Lingkungan merupakan salah satu cara untuk dapat mengembangkan nilai karakter dalam diri siswa [18]. Kerjasama yang baik dengan orang tua siswa di rumah dan juga teman- teman sekelas membuat perkembangan kedisiplinan berkembang dengan sanat tepat. Namun, selain keempat pendukung tersebut, terdapat salah satu faktor yang sangat besar untuk mendapatkan kedisiplinan pada diri siswa yaitu kesadaran dari diri sendiri. Kesadaran dari diri sendiri siswa merupakan faktor yang sangat besar pengaruhnya karena merupakan faktor internal. Segala kondisi kita jika sudah diyakini dan dijalankan dengan senang maka perubahan kedisiplinan tersebut dapat berhasil.

\section{SIMPULAN}

Simpulan yang dapat diambil dari hasil penelitin yang dilakukan adalah 1) Perkembangan sikap disiplin siswa dapat dilihat dari indikator disiplin siswa di kelas III SD Negeri 2 Sriti menunjukkan perkembangan yang cukup baik; 2) Faktor-faktor yang mempengaruhi perkembangan disiplin siswa di kelas III SD Negeri 2 Sriti terdiri dari dua factor, yaitu factor internal yang berasal dari dalam diri siswa sendiri dan faktor eksternal yang terdiri dari guru kelas, pihak sekolah, orang tua siswa, maupun teman-teman sekelas dan lingkungan.

Saran-saran yang dapat ditulis dari hasil penelitian yang telah dilakukan adalah sebagai berikut. 1) Peraturan sekolah sebaiknya dipajang di sekitar wilayah sekolah aagr semua warga sekolah dapat membaca dan menjalankan peraturan tersebut; 2) Guru kelas sebaiknya mengembangkan karakter disiplin secara berkelanjutan, tidak hanya sesuai pada saat tema tertentu yang mengharuskan penanaman karakter kedisiplinan; 3) Peneliti selanjutnya, sebaiknya dilakukan dalam waktu yang lebih lama lagi, dan dilaksanakan pada kelas yang lebih rendah.

\section{REFERENCES}

[1] Peraturan Presiden Republik Indonesia Nomor 87 Tahun 2017 tentang penguatan pendidikan karakter.

[2] Andi Tenri Faradiba dan Lucia R.M. Royanto, "Karakter Disiplin, Penghargaan dan Tanggung Jawab dalam Kegiatan Ekstrakurikuler", Jurnal Sains Psikologi, vol. 7, no. 1, pp. 93- 98, 2018, [Online]. Available: http://journal2.um.ac.id/index.php/JSPsi/article/view/2928/2106

[3] Ati Putry Julia, "Peranan Guru dalam Meningkatkan Karakter Disiplin dan Kejujuran Siswa", Jurnal Dedikasi Pendidikan, vol 03, no. 02, 2019, pp. 112-122, 2019, [Online] Available: http://jurnal.abulyatama.ac.id/index.php/dedikasi/article/view/278/pdf.

[4] Elmubarok, Z., Membumikan Pendidikan Nilai, 2009, Alfabeta, Bandung. 
[5] Rosma Elly, "Hubungan Kedisiplinan Terhadap Hasil Belajar Siswa Kelas V di SD Negeri 10 banda Aceh", Jurnal Pesona Dasar. vol. 3 no. 4, pp. 43-53, 2016, [Online] Available: http://www.jurnal.unsyiah.ac.id/PEAR/article/view/7540.

[6] Nur Rahmat, Sepriadi, dam Rasmi Daliana, "Pembentukan Karakter Disiplin Siswa Melalui Guru Kelas di SD Negeri 3 Rejosari Kabupaten Oku Timur", Jurnal Manajemen, Kepemimpinan dan Supervisi Pendidikan, vol 2, no. 2, pp. 229-244, 2017, [Online] Available: $\quad$ https://media.neliti.com/media/publications/230855-pembentukan-karakterdisiplin-siswa-mela-004867de.pdf

[7] Ma'sumah, Siti. 2015. Pengaruh Disiplin Belajar terhadap Prestasi Belajar Siswa Kelas IV Sekolah Dasar Negeri se-Daerah Binaan II Kecamatan Petanahan Kabupaten Kebumen. Skripsi Tidak Diterbitkan. Semarang: Jurusan Pendidikan Guru Sekolah Dasar, Fakultas Ilmu Pendidikan, Universitas Negeri Semarang.

[8] Njoroge, Philomena Mukami and Ann Nduku Nyabuto, "Discipline as a Factor in Academic Performance in Kenya". Journal of Educational and Social Research, vol. 4, no. 1, 2014, [Online] Available: https://www.mcser.org/journal/index.php/jesr/article/view/1847

[9] Anitah, Sri, Media Pembelajaran, 2009, Panitia Sertifikasi Guru Rayon 13 FKIP UNS Surakarta, Surakarta.

[10] Sugeng Hatyono, "Pengaruh Kedisiplinan Siswa dan Motivasi Belajar Terhadap Prestasi Belajar Siswa Pada Mata Pelajaran Ekonomi”, Jurnal Ilmiah Kependidikan, vol. 3, no. 3, pp. 261-274, 2016, [Online] Available: https://journal.lppmunindra.ac.id/index.php/Faktor/article/viewFile/939/874

[11] Shofwatul Badi'ah, "Penerapan Disiplin Melalui Budaya Sekolah pada Siswa Kelas VA SD Negeri Pujokusuman 1 Yogyakarta", Jurnal Pendidikan Guru Sekolah Dasar, vol. 5, no. $1, \quad 2016, \quad$ [Online] Available: http://journal.student.uny.ac.id/ojs/index.php/pgsd/article/view/242.

[12] Mastur, "Implementasi Kurikulum 2013 Dalam Pelaksanaan Pembelajaran di SMP", Jurnal Inovsi Teknologi Pendidikan, vol. 4, no. 1, pp. 50-64, 2017, [Online] Available: https://journal.uny.ac.id/index.php/jitp/article/view/10131/9313.

[13] Kartinah Kartinah, "Pengembangan Instrumen Pengukuran Disiplin untuk Siswa Sekolah Menengah Pertama", Jurnal Penelitian dan Evaluasi Pendidikan, vol. 6, no. 2, pp. 102108, 2018, [Online] Available : http://jurnal.ustjogja.ac.id/index.php/wd.

[14] Musfiqon, Metodologi Penelitian Pendidikan, 2012, Prestasi Pusdakarya, Jakarta.

[15] Miles, Mattew B dan Amichael Huberman, Analisis Data Kualitatif Buku Sumber tentang Metode-Metode Baru, Terjemahan Tjetjep Rohendi Rohisi, 2007, Universitas Indonesia, Jakarta.

[16] Hurlock, Elizabeth, B, Psikologi Perkembangan, 2011, Erlangga, Jakarta.

[17] Sudrajat, A. \& Wibowo, A. Pembentukan Karakter Terpuji di Sekolah Dasar Muhammadiyah Condongcatur. Jurnal Pendidikan Karakter, vol. 1, no.2, pp. 174- 185, 2013, [Online] Available: https://journal.uny.ac.id/index.php/jpka/article/view/1438

[18] A. Mumpuni and M. S. Masruri, "Muatan Nilai-Nilai Karakter Pada Buku Teks Kurikulum 2013 Pegangan Guru Dan Pegangan Siswa Kelas II," Jurnal Pendidikan Karakter, no. 1, pp. 17-28, 2016, [Online] Available: https://journal.uny.ac.id/index.php/jpka/article/view/10728/8084 